\title{
Treatment of tannery wastewater using aluminium formate: influence of the formate over sulphate-based coagulant
}

\author{
Arukula D., Prem P., Tanwi P., Hariraj S., Vijay L.M. and Brijesh K.M. ${ }^{*}$ \\ Department of Environmental science and Engineering \\ Indian Institute of Technology (Indian School of Mines) Dhanbad, Jharkhand, India \\ Received: 20/11/2017, Accepted: 27/08/2018, Available online: 26/09/2018 \\ *to whom all correspondence should be addressed: e-mail: brijesh@iitism.ac.in
}

\begin{abstract}
Tannery industries provoke the conspicuous quantity of deleterious effluent which has to be treated prior to discharge into the environment. Pre-treatment of tannery wastewater with aluminium sulphate is well known over decades, but due to the corrosive nature of sulphate this pre-treated water causes several issues in the biological treatment system. To overcome this issue a study was performed to understand the coagulant activity of aluminium formate and aluminium sulphate. The effect of coagulant activity as a function of $\mathrm{pH}$ and coagulant dose of Aluminium formate was studied and found that it surpassed aluminium sulphate in terms of $\mathrm{Cr}(\mathrm{VI})$, sulphate and COD removal by $10 \%, 6 \%$ and $10 \%$ respectively, while turbidity removal for both coagulants was found approximately equal. Possible mechanistic approach to the coagulation property of aluminium formate and aluminium sulphate could be inter particle bridging and sweep coagulation respectively. Formate [ $\left.\mathrm{HCOO}^{-}\right]$can be utilized as a counter anion in the place of commonly used sulphate anions as it is biodegradable, non-toxic and corrosive free compound. Therefore, Aluminium formate can be a promising coagulant for the pre-treatment of tannery wastewater.
\end{abstract}

Keywords: Tannery wastewater, coagulation, Aluminium formate, Hexavalent chromium, Formate ion.

Abbreviations: AF, Aluminium formate; AS, Aluminium sulphate; COD, Chemical Oxygen demand; UV, Ultraviolet; BOD, Biochemical Oxygen demand; $\mathrm{Cr}(\mathrm{VI})$, Hexavalent Chromium; [HCOO-], Formate ion.

\section{Introduction}

Although leather industry is presently undergoing a drastic conversion due to increasing pollution and discharge legislations (Deghles and Kurt, 2016); however, in developing countries like Turkey, China, India, Pakistan, Brazil and Ethiopia (Lefebevre et al., 2006; Banu and Kalippan, 2007), tanneries represent the prodigious economic input. Among them, the Indian leather industry is $6^{\text {th }}$ largest in the world and it is one of the top ten foreign exchange earners for the country. More than three thousand tanneries are present in India and around 80\% are under small scale sector (Sharma and Adholeya, 2011) but regrettably it is an important source of pollution. Tanneries necessitate a series of chemical treatments and mechanical operations to accomplish the require traits (Elabbas et al., 2016). During the chrome tanning process, $\mathrm{Cr}(\mathrm{VI})$ is used for tanning that ingest $30-35 \mathrm{~L}$ of water per $\mathrm{kg}$ of skin. However, $40 \%$ of $\mathrm{Cr}(\mathrm{VI})$ salts are frequently remitted into the final effluents which causes a serious threat to the environment and distress to the internal organs as well as external organs of the human body such as kidney, liver, respiratory tract, skin etc., it also deforms the DNA, which leads to the genetic transformation (Barrera-Diaz et al., 2012; Dalcin et al., 2011). In addition, it provokes $90 \%$ of used water as effluent which comprise high amount organic matter, suspended solids, $\mathrm{BOD}, \mathrm{Cr}(\mathrm{VI})$, COD and Sulphate (Aboulhassan et al., 2008). The pollutants with high concentration as well as low biodegradability represent an increasing environmental alarm with regard to environmental challenge (Schrank et al., 2009).

The treatment of tannery wastewater is more complicated due to the accumulation of complex organic and inorganic compounds. Many researchers have reported the Pretreatment technologies of tannery wastewater; some of the methods like i.e., flotation, electrochemical treatment, sedimentation, coagulation, filtration, ultra-filtration, reverse osmosis process (Song et al., 2008). Coagulation or chemical precipitation has been known for wastewater treatment over centuries, where lime was used as coagulant alone and/or in combination with cationic or anionic polymers which increases treatment efficiency. In addition, the $\mathrm{pH}$ and coagulant dose plays a vital role as it helps in the agglomeration of slow-settling micro-flocs into larger-denser flocs (Radio et al., 2004; Liu et al., 2012). Among these pre-treatment methods, coagulation/flocculation process is one of the most simple, efficient and considered technique to improve the biodegradability and fouling of tannery wastewater. In addition, it is suitable to enhance the effectiveness of subsequent treatment and to provide low cost and efficient biological treatment (Shammas, 2005). Depending on the contaminant and the type of coagulant in pre-treatment process with high efficiencies, it removes COD, turbidity, 
sulphate and heavy metals (Maranon et al., 2008). Aluminium sulphate $\left[\mathrm{Al}_{2}\left(\mathrm{SO}_{4}\right)_{3}\right]$ and ferric chloride $\left[\mathrm{FeCl}_{3}\right]$ salts are commonly used coagulants to treat tannery wastewater. Aluminium sulphate has advantages over Ferric salts in many ways as it is comparatively better in case of the degree of interaction between aluminium cations, the target principal contaminant $\mathrm{Cr}(\mathrm{VI})$ and its easy availability as well as cost-effectiveness (Mella et al., 2015). The drawbacks of using ferric salts in tannery wastewater treatment are during unharing process, it produces dark black color due to the formation of Iron sulfide (Sayers and Langlais, 1977). Some researchers had found that due to the usage of coagulants aluminium and ferric salts in huge dose leads to the residual metal in treated water as well as sludge produced by metal salts is normally porous, incompact and difficult to dewater as it has high moisture contents of 99-99.7\% (Zhao and Bache, 2002). In tannery wastewater, chloride and sulphates are one of the major problems in biological treatments due to the high concentration of Chloride which retards biodegradation of dissolved organics and sulphate also causes corrosiveness to various materials during pre-treatment of coagulation process (Maharaja et al., 2017; Mikola and Tanskanen, 2015). In order to overcome these problems, it is necessary to find an alternate coagulant to treat the wastewater with no toxic effects.

The objective of the present study is to evaluate coagulant activity of Formate [HCOO-], which can be used as a counter anion by substituting commonly used sulphate and chloride anions in aluminium coagulants. The reason to consider coagulant is that, it is less corrosive than chloride and sulphate and can be decomposed easily and agglomeration of anions in treated water can be eluded (Vaananen et al., 2012; Talu and Diyamandoglu, 2004). Biodegradability empowers the processed water to be used in irrigation without causing salinization of the soil and also the other prospective of the formate anion can be used to aggrandize the performance of biological process which follows coagulation as a pre-treatment (Mikola and Tanskanen, 2015).

In the present study, the effect of operational conditions was examined and optimization of coagulant behaviour was scrutinized, on the basis of the coagulant activity for removal of $\mathrm{Cr}(\mathrm{VI})$ and also elaborated the other factors such as COD, turbidity and sulphate. The possible mechanism of aluminium formate coagulant was also compared with that of traditional aluminium sulphate coagulant with the help of SEM analysis.

\section{Materials and methods}

\subsection{Chemicals and reagents}

\subsubsection{Chemicals for Physico-chemical analysis}

1,5-Diphenylcarbazide $\left(\mathrm{C}_{13} \mathrm{H}_{14} \mathrm{ON}_{4}\right)$, Sodium Acetate $\left(\mathrm{C}_{2} \mathrm{H}_{3} \mathrm{NaO} .3 \mathrm{H}_{2} \mathrm{O}\right)$, Potassium Nitrate $\left(\mathrm{KNO}_{3}\right)$, Ferrous Ammonium Sulphate Hexahydrate $\left(\mathrm{Fe}\left(\mathrm{NH}_{4}\right)_{2}\left(\mathrm{SO}_{4}\right)_{2} \cdot 6 \mathrm{H}_{2} \mathrm{O}\right)$, were procured from Loba Chemie, India, Acetone $\left(\mathrm{CH}_{3} \mathrm{COCH}_{3}\right)$, Nitric acid $\left(\mathrm{HNO}_{3}\right)$, Magnesium chloride Hexahydrate $\left(\mathrm{MgCl}_{2} .6 \mathrm{H}_{2} \mathrm{O}\right)$, Acetic acid $\left(\mathrm{CH}_{3} \mathrm{COOH}\right)$, Barium chloride $\left(\mathrm{BaCl}_{2} .2 \mathrm{H}_{2} \mathrm{O}\right)$, Ammonium chloride $\left(\mathrm{NH}_{4} \mathrm{Cl}\right)$, Aluminium sulphate $\left[\mathrm{Al}_{2}\left(\mathrm{SO}_{4}\right)_{3}\right]$, Sodium chloride $(\mathrm{NaCl})$, Sodium hydroxide $(\mathrm{NaOH})$, Ferroin indicator solution were purchased from Merck, India. Silver Sulphate purified $\left(\mathrm{Ag}_{2} \mathrm{SO}_{4}\right)$ was brought from Central Drug House (P) LTD, India.

\subsubsection{Reagents used for synthetic tannery waste water}

Potassium dichromate $\left(\mathrm{K}_{2} \mathrm{Cr}_{2} \mathrm{O}_{7}\right)$, Kaolin, Humic acid, Barium Sulphate $\left(\mathrm{BaSO}_{4}\right)$, Calcium chloride $\left(\mathrm{CaCl}_{2} .2 \mathrm{H}_{2} \mathrm{O}\right)$, were purchased from Merck, India. Dipotassium hydrogen orthophosphate $\left(\mathrm{K}_{2} \mathrm{HPO}_{4} .3 \mathrm{H}_{2} \mathrm{O}\right)$ was supplied by Fisher Scientific, India. Aluminium Hydroxide $\mathrm{Al}\left(\mathrm{OH}_{3}\right)$ was provided by S.d. Fine-Chem (P) LTD, India and Formic Acid was brought from Sisco Research Laboratories (P) LTD, India. All the reagents were prepared in Millipore water (Merck, Germany).

\subsubsection{Preparation of synthetic tannery wastewater}

Synthetic tannery wastewater was prepared in laboratory conditions by simulating real tannery wastewater whose selected constituents were of Potassium dichromate $\left(\mathrm{K}_{2} \mathrm{Cr}_{2} \mathrm{O}_{7}\right) 100 \mathrm{mg} / \mathrm{L}$ was added in order to improve the $\mathrm{Cr}(\mathrm{VI})$ concentration in the solution. In addition, Humic acid powder was added as organic matter to make it as a real tannery waste water, whose required concentration and $\mathrm{pH}$ were prepared for optimization study in bench scale coagulation experiments.

\subsection{Synthesis of Aluminium formate}

Aluminium formate was synthesized by adding 3:1 ratio of Formic Acid and Aluminium Hydroxide as starting materials. The solution was heated carefully on a hot plate at a temperature of $45{ }^{\circ} \mathrm{C}$. As a result, a strong robust reaction takes place and the temperature was slightly increased to $90^{\circ} \mathrm{C}$ the solution was turned into solid form and dried in oven at $105^{\circ} \mathrm{C}$ for 20 (Mikola and Tanskanen, 2015). The formed solid was grinded using blender to convert into fine powder form.

\subsection{Preparation of metallic coagulant solution}

The coagulant solution of Aluminium formate $\left[\mathrm{C}_{3} \mathrm{H}_{3} \mathrm{AlO}_{6}\right]$ was prepared by dissolving $2.5 \mathrm{~g}$ in $250 \mathrm{ml}$ of distilled water. While the solution of aluminium sulphate $\left[\mathrm{Al}_{2}\left(\mathrm{SO}_{4}\right)_{3}\right]$ was prepared in the same separately. The solutions were mixed vigorously to get the homogenized solution of the respective coagulant.

\subsection{Optimization experiment}

Synthetic tannery wastewater was carried out using a jar test method (Scientific Engineering Corp., India) the predetermined $\mathrm{pH}$ was adjusted using $1 \mathrm{~N} \mathrm{H}_{2} \mathrm{SO}_{4} / 1 \mathrm{~N} \mathrm{NaOH}$, where the contents were continuously stirred, followed by the coagulant dose of aluminium formate and aluminium sulphate separately. The $\mathrm{pH}$ and dose of the coagulant varied from $6.0-8.5$ and $50-450 \mathrm{mg} / \mathrm{l}$ respectively. During the bench scale coagulation experiments, to control the unwanted dilution effects coagulant volume was maintained less than $5 \% \mathrm{v} / \mathrm{v}$ (aqueous solution basis) (Khayet et al., 2011). After the dose of coagulant, the 
paddle was rotated at a speed of $400 \mathrm{rpm}$ for $1 \mathrm{~min}$ and followed by a slow mixing of 20rpm for $15 \mathrm{~min}$ then the water was allowed to settle for $30 \mathrm{~min}$ to achieve floc growth (Vaananen et al., 2012) and $\mathrm{Cr}(\mathrm{VI})$ was measured using a UV Spectrophotometer for $\mathrm{pH}$ and dose optimization.

\subsection{Analytical methods}

The analysis of coagulant treated wastewater for various parameters like $\mathrm{pH}$, turbidity, conductivity, $\mathrm{Cr}(\mathrm{VI}), \mathrm{COD}$ and sulphate were measured as per prescribed method i.e. (APHA, 2012). The turbidity and $\mathrm{pH}$ were measured using a Digital turbidity meter (E. I, India) and bench scale $\mathrm{pH}$ meter (Hanna Instruments, Germany) respectively. Whereas $\mathrm{Cr}(\mathrm{VI})$ and Sulphate were measured using UV-Vis spectrophotometer (UV-Vis spectrophotometer, Labtech Model No. 91008) at $540 \mathrm{~nm}$ and $420 \mathrm{~nm}$ respectively using quartz cell as prescribed method i.e., ( APHA 2012). Cr(VI) was measured by taking $5 \mathrm{ml}$ of sample in a beaker and $\mathrm{pH}$ was adjusted to 1.0 by using $0.2 \mathrm{~N} \mathrm{HNO}_{3}$ and then the sample was make up to $100 \mathrm{ml}$ using the distilled water. $2 \mathrm{ml}$ of DCP (1,5-Diphenylcarbazide $\left.\left(\mathrm{C}_{13} \mathrm{H}_{14} \mathrm{ON} 4\right)\right)$ solution which was prepared by dissolving $250 \mathrm{mg}$ in $50 \mathrm{ml}$ of acetone was added and left to stand for 5 minutes to develop pink colour and the readings were taken by using the spectrophotometer immediately. Sulphate measurement was carried out by taking $100 \mathrm{ml}$ of filtered sample in a beaker in which $20 \mathrm{ml}$ of freshly prepared buffer solution was added as the method reported by

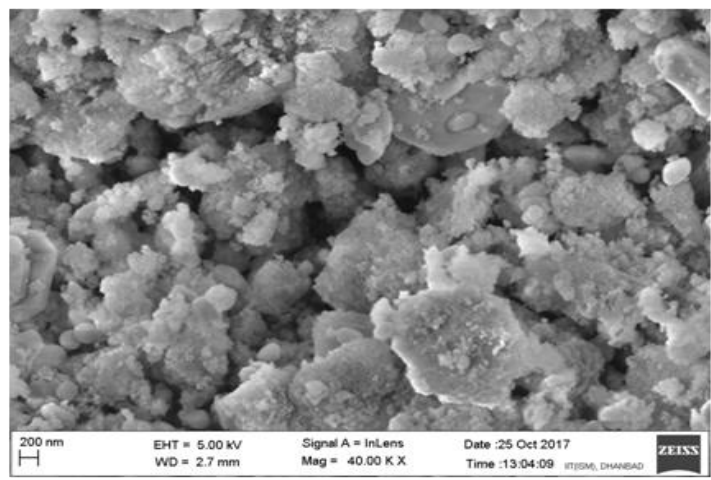

(a)
(APHA, 2012) and a pinch of Barium chloride $\left(\mathrm{BaCl}_{2} .2 \mathrm{H}_{2} \mathrm{O}\right)$, was added to form a white precipitate and the readings were taken at $420 \mathrm{~nm}$ using spectrophotometer. COD was measured by a close reflux method using COD digester $(\mathrm{HI}$ 839800 Hanna Instruments, Germany) and morphological study were carried out using an SEM analyser (Zeisis, Germany). All experiments were conducted in triplicates for reproducibility purpose.

\subsection{Morphological characteristics of coagulants (SEM} analysis)

The morphological characteristics of the agglomerates of aluminium formate and aluminium sulphate were examined by using scanning electron micrographs. Fig. 1(a) depicts the presence of small globular structure on the surface of aluminium formate, which corresponds to an occurrence of the interparticle bridging phenomenon among flocs. In Fig. 1(b), flocs of bigger size were observed, which reveals honeycomb structure of agglomeration and it elicits the possibility of adsorbed colloidal particles inside the porous structure of aluminium sulphate. Though aluminium formate might not be as efficient as aluminium sulphate in floc formation, but it poses the ability to adhere small flocs together by this we can conclude that interparticle bridging and sweep flocculation could be the possible mechanistic approach for aluminium formate and aluminium sulphate coagulants respectively (Miller et al., 2008).

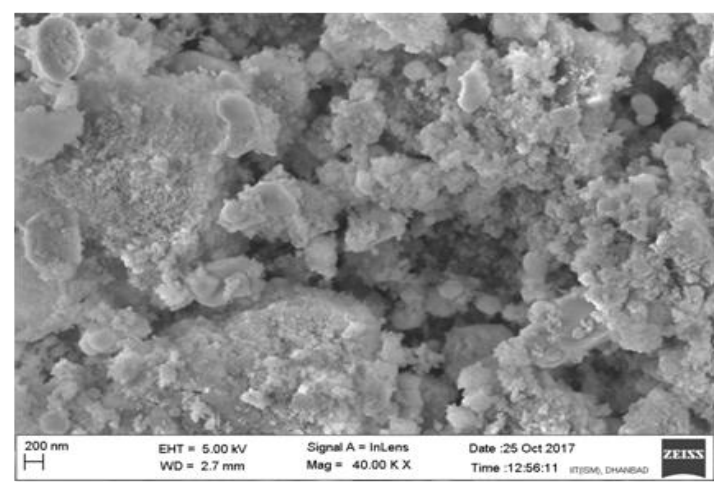

(b)

Figure 1. (a) and (b) depicts the FE-SEM analysis of aluminium formate and aluminium sulphate

\section{Results and discussion}

\subsection{Characteristics of raw tannery wastewater}

To evaluate the coagulant activity of two aluminium species coagulants namely aluminium formate and sulphate, the real tannery wastewater samples were collected from the leather complex of Calcutta and the concentration of different pollutants was monitored. Based on the physico-chemical analysis and different literatures on actual tannery wastewater, the synthetic tannery wastewater was prepared.

Table 1 represents the concentration of different physicochemical characteristics of real and synthetic tannery wastewater.
To understand the coagulant activity of aluminium formate $\mathrm{Cr}(\mathrm{VI})$, sulphate, turbidity, and COD were selected as the variable parameters for the optimization study during coagulation.

\subsection{Optimization study}

The optimum $\mathrm{pH}$ and dose for coagulation was determined based on the removal efficiency of $\mathrm{Cr}(\mathrm{VI})$ reduction at various $\mathrm{pH}$ and coagulant dosages. The effect of $\mathrm{pH}$ at initial $\mathrm{Cr}(\mathrm{VI})$ concentration of $100 \mathrm{mg} / \mathrm{L}$ and dose of coagulant has been shown in Fig. 2(a) and Fig. 2(b) respectively. 
Table 1. Physico-Chemical characteristics of raw and synthetic tannery wastewater

\begin{tabular}{ccc}
\hline Parameters & Actual Conc & Synthetic conc \\
\hline $\mathrm{pH}$ & 9 & 9.4 \\
\hline Conductivity $(\mu \mathrm{s} / \mathrm{cm})$ & 12900 & 11860 \\
\hline Total dissolved solids $(\mathrm{mg} / \mathrm{L})$ & 6900 & 5782 \\
\hline Sulphate $(\mathrm{mg} / \mathrm{L})$ & 916 & 760 \\
\hline Chemical oxygen demand $(\mathrm{mg} / \mathrm{L})$ & 17600 & 16000 \\
\hline Turbidity (NTU) & 87 & 82 \\
\hline Cr(VI) (mg/L) & 120 & 100 \\
\hline Chlorides (mg/L) & 1200 & 599.8 \\
\hline
\end{tabular}

*conc- Concentration

\subsection{Effect of $\mathrm{pH}$ on $\mathrm{Cr}(\mathrm{VI})$ removal}

$\mathrm{Cr}(\mathrm{VI})$ oxidation state is more lethal than $\mathrm{Cr}(\mathrm{III})$ state due to high solubility and mobility of the oxy-anion forms, which exists in two forms namely, chromate anions in acidic condition as hydrogen chromate $\left(\mathrm{HCrO}_{4}{ }^{-}\right)$and chromate anions $\left(\mathrm{CrO}_{4}{ }^{2-}\right)$, which is dominant species in alkaline medium (Aroua et al., 2007). The $\mathrm{pH}$ plays crucial role in the removal of $\mathrm{Cr}(\mathrm{VI})$ from tannery wastewater. Results showed that $70-80 \%$ of $\mathrm{Cr}(\mathrm{VI})$ was removed in alkaline condition while lower coagulant activity was observed at acidic $\mathrm{pH}$, which might be due to the occurrence of competition between protons and metal ions for common binding sites under acidic condition (Sutherland et al., 1989; Song et al., 2004; Chowdhury et al., 2013). Fig. 2(b) depicts the influence of coagulant dose on the removal of $\mathrm{Cr}(\mathrm{VI})$ at an optimum $\mathrm{pH} 7.5$, as the dose of the aluminium species coagulant increases at a rate of $50 \mathrm{mg} / \mathrm{L}$, the removal efficiency of $\mathrm{Cr}(\mathrm{VI})$ was increased up-to optimized dose for both the coagulants.

\subsection{Effect of coagulant dose on Cr(VI) removal}

Fig. 2(a) illustrates the increasing $\mathrm{Cr}(\mathrm{VI})$ removal efficiency of both coagulants, aluminium formate and aluminium sulphate with the increase in $\mathrm{pH}$, which might be due to the generation of aluminium bridged oligomers and high polymers (as a result of hydrolysis of aluminium species). Due to these reactions, the efficiency of the coagulant was

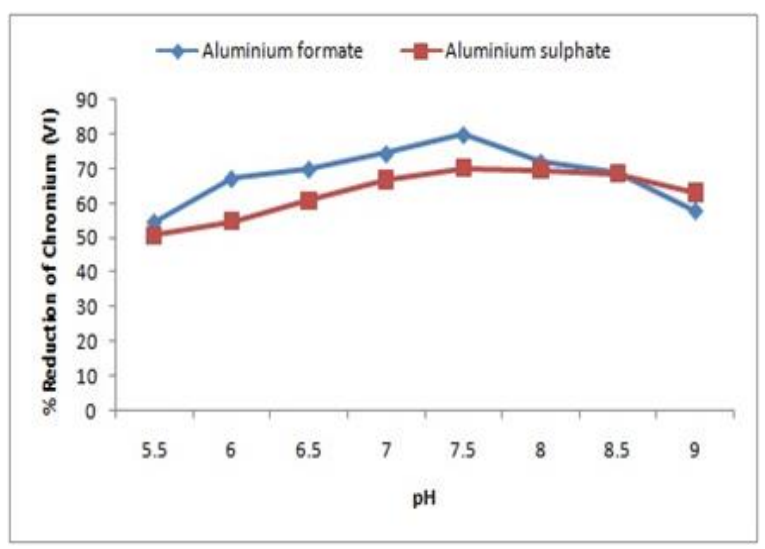

(a) also improved through electrostatic interactions of colloid species (Wilson, 2014). The maximum percentage removal, nearly $80 \% \mathrm{Cr}(\mathrm{VI})$ was observed in case of aluminium formate; the reason might be that the aluminium formate $\left(\mathrm{C}_{3} \mathrm{H}_{3} \mathrm{AlO}_{6}\right)$, decomposes into Aluminium $\left(\mathrm{Al}^{+3}\right)$ and formate ions $\left(\mathrm{HCOO}^{-}\right)$in the synthetic tannery wastewater. The formate ion ( $\left.\mathrm{HCOO}^{-}\right)$further dissociates and releases $\mathrm{CO}_{2}$ and $\mathrm{H}^{+}$ions. Moreover, $\mathrm{H}^{+}$ions react with $\mathrm{Cr}(\mathrm{VI})$ present in the synthetic tannery wastewater and thereby gets reduced to $\mathrm{Cr}$ (III) and these $\mathrm{Cr}$ (III) has a tendency to bind with $\mathrm{OH}^{-}$ions and precipitates as Chromium hydroxide $\left[\mathrm{Cr}(\mathrm{OH})_{3}\right]$. Fig. 2(b) shows that the removal efficiency of $\mathrm{Cr}(\mathrm{VI})$ in case of aluminium formate reduces after optimized dose i.e. $200 \mathrm{mg} / \mathrm{l}$. The decline in removal efficiency after optimized dose was because of restabilization effect, as the coagulant dose surpassed the threshold level (Chowdhury et al., 2013). Whereas in the case of aluminium sulphate, maximum $70 \% \mathrm{Cr}(\mathrm{VI})$ removal was observed at a dose of $350 \mathrm{mg} / \mathrm{l}$. The low removal efficiency of $\mathrm{Cr}(\mathrm{VI})$ was due to the slow hydrolysis rate of the aluminium sulphate, because the counter anion present in aluminium sulphate to some extent binds to the positive sites of the impurity particles as a result increase in the negative net charge of the pollutants. Due to this phenomenon higher dose of coagulant is needed for charge neutralization in order to precipitate out the pollutants (Saukkoriipi, 2010).

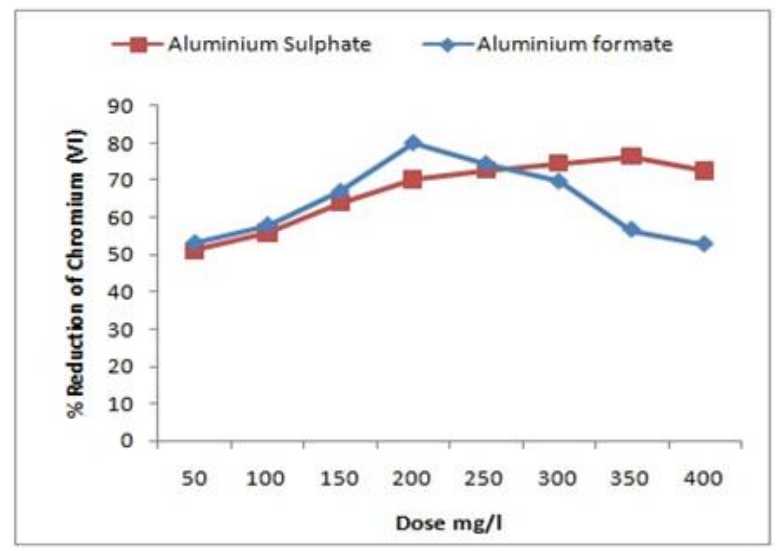

(b)

Figure 2. Effect of coagulant on $\mathrm{Cr}(\mathrm{VI})$ removal as a function of $(\mathrm{a}) \mathrm{pH}$ (b) Dose 


\subsection{Effect of coagulants on removal of Turbidity}

Turbidity is a measure of water quality and is a measurement methodology that involves light reflection which passes through water without being absorbed and scattered. In the Fig. 3 , it shows that at an optimum $\mathrm{pH}$ both Aluminium formate and aluminium sulphate coagulants exhibited the removal efficiency of turbidity almost nearly about $90 \%$ and $94 \%$ respectively with the increase of the coagulant dose and results in a decrease of residual turbidity. It was perceived that as the dose of aluminium coagulants reached to an optimum value there was no further decrease in the residual turbidity, which signify that over dose of coagulant leads to re-stabilization of colloidal particles (Yan et al., 2007). In aluminium formate (organic) coagulant size of the floc was comparatively smaller with that of aluminium sulphate. However, it showed better particle agglomeration resulting in adhesion of organic and inorganic contaminants this might be due to interparticle bridging. But in the case of aluminium sulphate at higher $\mathrm{pH} \mathrm{6-8} \mathrm{formation} \mathrm{of} \mathrm{Al}(\mathrm{OH})_{3}$ was significant where at lower $\mathrm{pH} \mathrm{Al}^{+3}$ were present in considerable amount which are effective in coagulation because they destabilize the negatively charged impurity particles entrapped and precipitates as flocs as a result the efficiency of turbidity was increased the possible mechanism might be sweep flocculation (Kim et al., 2007).

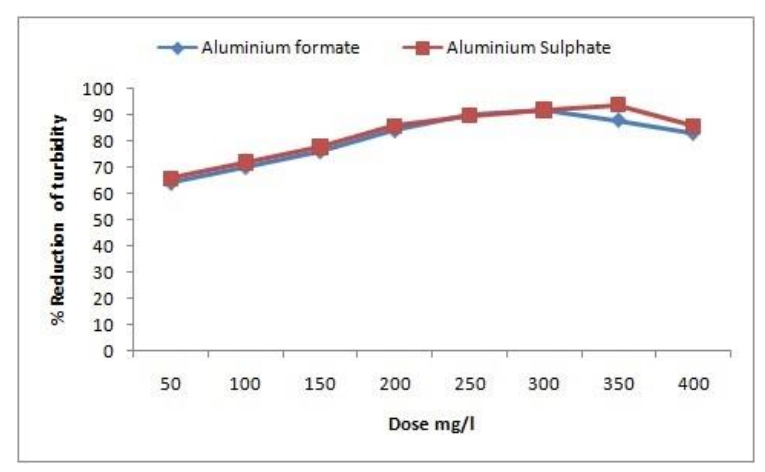

Figure 3. Effect of coagulant dose on the removal of turbidity

\subsection{Effect of coagulant dose on the removal of sulphate}

High concentrations of sulphate can lead to environmental problems, corrosion and scaling of equipment (Lens and Pol, 2000). In fig 4, the graph illustrates that at an optimum $\mathrm{pH}$ the coagulant species of aluminium format showed its maximum removal efficiency nearly about $74 \%$ at a low dose concentration, aluminium formate decomposes into aluminium and formate anions. The aluminium binds with the counter anion sulphate which is present in tannery wastewater and forms aluminium sulphate. This aluminium sulphate has the capability to generate aluminium hydroxide precipitates at neutral/ alkaline $\mathrm{pH}$, which are either positively or negatively charged by the adsorption of hydroxometallic ions onto the surface. Thus, this surface charge can modify the probability for the fixation of sulphate ions conspicuously. Similar mechanism occurred for the removal of sulphate anions in the case of aluminium sulphate coagulant. The removal efficiency of aluminium sulphate was low as compared to aluminium formate coagulant, because high dose of aluminium sulphate caused a reduction in removal efficiency due to the higher solubility of aluminium species and the increased $\mathrm{pH}$. The reason might be negatively charged surface of the aluminium hydroxide precipitates associated with the adsorption of alumina hydroxo anions, which prevents the adsorption of sulphate (Canizares et al., 2008; Lacasa et al., 2013; Mamelkina et al., 2017). Mamelkina et al., (2017) also reported that, higher solubility of sulphate increases the $\mathrm{pH}$ level up to 12 which reduced the removal efficiency of sulphate ions significantly in the wastewater.

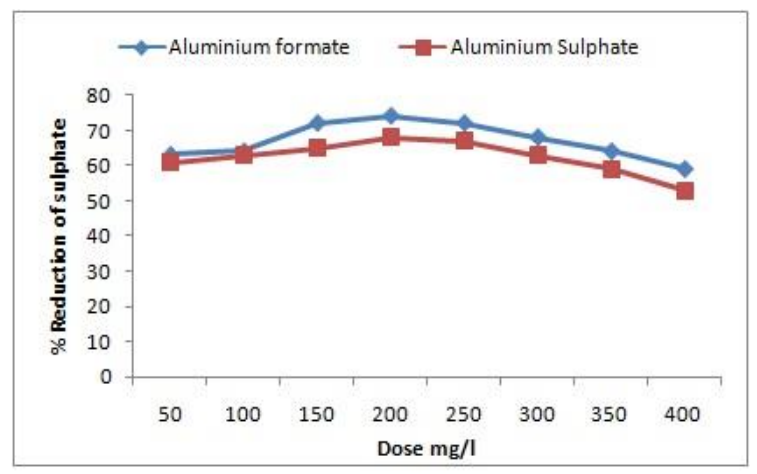

Figure 4. Effect of coagulant dose on reduction of sulphate

\subsection{Effect of coagulant on the removal of COD}

The COD removal efficiency was found about $70 \%$ using aluminium formate coagulant, while aluminium sulphate showed low percentage removal nearly about $60 \%$. Fig 5 elucidates that at optimum $\mathrm{pH}$, the removal of COD was increased with an increase in the dose of the coagulant until it reaches to the optimum value and started to retrograde.

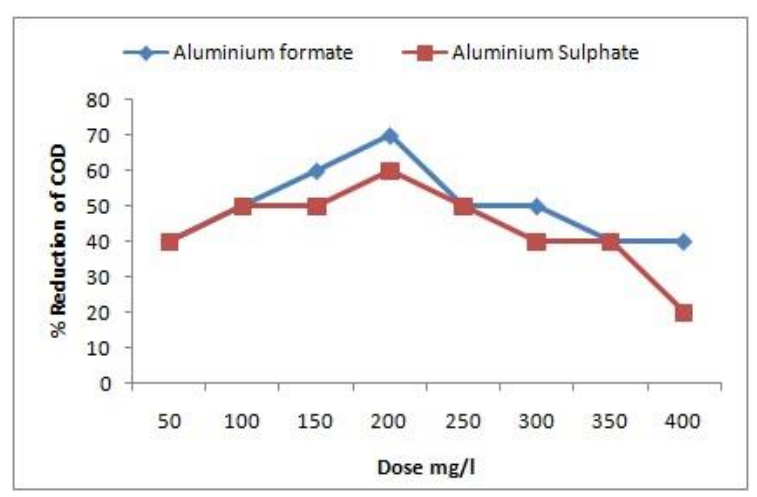

Figure 5. Effect of coagulant dose on the removal of COD

In aluminium formate, the organic and inorganic suspended contaminants adhere on the surface might be due to interparticle bridging. However, as the dose of the coagulant increases the surface charge of the particles will be reversed at higher dose due to uninterrupted adsorption of mono and polynuclear species of the coagulant. In aluminium sulphate the maximum particle removal occurred by sweep flocculation due to the 
synchronized effect of charge neutralization and adsorption of aluminium ions, hydrolyzed aluminium flocs enmeshed the colloids and drown them to settle down (Verma et al., 2010; Srivastava et al., 2005; Garg et al., 2005).

\section{Conclusion}

In the present study, the coagulation efficiency of aluminium formate, which was synthesized from aluminium hydroxide with the reaction of formic acid was assessed for the treatment of tannery wastewater. The effectiveness of aluminium formate over aluminium sulphate was evaluated under different operational conditions and the results were compared in terms of $\mathrm{Cr}$ $(\mathrm{VI})$, sulphate, and COD removal efficiency. The higher $\mathrm{Cr}(\mathrm{VI})$ removal efficiency was achieved using aluminium formate over aluminium sulphate even at a low dose concentration, which might be due to the decomposition of aluminium formate, which further dissociates and releases $\mathrm{CO}_{2}$ and $\mathrm{H}^{+}$ions as a result $\mathrm{H}^{+}$ions reacts with $\mathrm{Cr}(\mathrm{VI})$ and reduces to $\mathrm{Cr}(\mathrm{III})$, which has a tendency to bind with $\mathrm{OH}^{-}$ions and precipitates as $\mathrm{Cr}(\mathrm{OH})_{3}$. The high sulphate removal may be attributed as aluminium binds with sulphate which produces aluminium hydroxide precipitates at neutral/alkaline $\mathrm{pH}$ and acts as a primary coagulant species and reduces sulphate ions in a quick response time. Literature also suggested that Formate acts as counter anion and has more advantages over sulphates and chlorides due to its less corrosiveness and no toxic effects. Aluminium formate may acts as a carbon source from the coagulant that may be used as a nutrient in biological processes. Based on the above facts, Aluminium formate is a promising prospective coagulant that can be used in the place of aluminium sulphate for the treatment of tannery wastewater.

\section{Acknowledgements}

Authors acknowledge financial support from Indian Institute of Technology (Indian School of Mines), Dhanbad under Junior Research Fellowship scheme funded by Ministry of Human Resource Development (MHRD), Government of India, New Delhi to carry out this research work.

\section{References}

Aboulhassan M.A., Souabi S. and Yaacoubi A. (2008), Pollution reduction and biodegradability index improvement of tannery effluents, International Journal of Environmental Science and Technology, 5(1), 11-16.

APHA-AWWA-WEF (2012), Standard methods for the examination of water and wastewater, 22nd Edition, Washington, D.C.

Aroua M.K., Zuki F.M. and Sulaiman N.M. (2007), Removal of chromium ions from aqueous solutions by polymer-enhanced ultrafiltration, Journal of Hazardous Materials, 147(3), 752-758.

Barrera-Diaz C.E., Lugo-Lugo V. and Bilyeu B. (2012), A review of chemical, electrochemical and biological methods for aqueous Cr (VI) reduction, Journal of Hazardous Materials, 223, 1-12.

Canizares P., Martínez F., Rodrigo M.A., Jiménez C., Saez C. and Lobato J. (2008), Modelling of wastewater electrocoagulation processes: Part I. General description and application to kaolin-polluted wastewaters., Separation and Purification Technology, 60(2), 155-161.

Chowdhury M., Mostafa M.G., Biswas T.K. and Saha A.K. (2013), Treatment of leather industrial effluents by filtration and coagulation processes, Water Resources and Industry, 3, 11-22.

Dalcin M.G., Pirete M.M., Lemos D.A., Ribeiro E.J., Cardoso V.L. and de Resende M.M. (2011), Evaluation of hexavalent chromium removal in a continuous biological filter with the use of central composite design (CCD), Journal of Environmental Management, 92(4), 1165-1173.

Deghles A. and Kurt U. (2016), Treatment of tannery wastewater by a hybrid electrocoagulation/electrodialysis process, Chemical Engineering and Processing: Process Intensification, 104, 43-50.

Elabbas S., Ouazzani N., Mandi L., Berrekhis F., Perdicakis M., Pontvianne S. and Leclerc J.P. (2016), Treatment of highly concentrated tannery wastewater using electrocoagulation: influence of the quality of aluminium used for the electrode, Journal of Hazardous Materials, 319, 69-77.

Garg A., Mishra I.M. and Chand S. (2005), Thermochemical precipitation as a pre-treatment step for the chemical oxygen demand and color removal from pulp and paper mill effluent, Industrial \& Engineering Chemistry Research, 44(7), 2016-2026.

Khayet M., Zahrim A.Y. and Hilal N. (2011), Modelling and optimization of coagulation of highly concentrated industrial grade leather dye by response surface methodology, Chemical Engineering Journal, 167(1), 77-83.

Kim S., Park N.S., Kim T. and Park H. (2007), Reaggregation of flocs in coagulation-cross-flow microfiltration, Journal of Environmental Engineering, 133(5), 507-514.

Lacasa E., Canizares P., Sáez C., Martínez F. and Rodrigo M.A. (2013), Modelling and cost evaluation of electro-coagulation processes for the removal of anions from water, Separation and Purification Technology, 107, 219-227.

Lefebvre O. and Moletta R. (2006), Treatment of organic pollution in industrial saline wastewater: a literature review, Water Research, 40(20), 3671-3682.

Lens P. and Pol L.H. eds., (2000), Environmental technologies to treat sulfur pollution, IWA publishing.

Liu X., Li X. M., Yang Q., Yue X., Shen T.T., Zheng W. and Zeng G.M. (2012), Landfill leachate pre-treatment by coagulationflocculation process using iron-based coagulants: optimization by response surface methodology, Chemical Engineering Journal, 200, 39-51.

Maharaja P., Mahesh M., Chitra C., Kalaivani D., Srividya R., Swarnalatha S. and Sekaran G. (2017), Sequential oxic-anoxic bio reactor for the treatment of tannery saline wastewater using halophilic and filamentous bacteria, Journal of Water Process Engineering, 18, 47-57.

Mamelkina M.A., Cotillas S., Lacasa E., Saez C., Tuunila R., Sillanpaa M. and Rodrigo M.A. (2017), Removal of sulfate from mining waters by electrocoagulation, Separation and Purification Technology, 182, 87-93.

Maranon E., Castrillon L., Fernandez-Nava Y., Fernandez-Méndez A. and Fernandez-Sanchez A. (2008), Coagulationflocculation as a pre-treatment process at a landfill leachate nitrification-denitrification plant, Journal of Hazardous Materials, 156(1), 538-544. 
Mella B., Glanert A.C and Gutterres M. (2015), Removal of chromium from tanning wastewater and its reuse, Process Safety and Environmental Protection, 95, 195-201.

Mikola M. and Tanskanen J. (2015), Preparation and coagulation performance of solid aluminium formate, Journal of Water Process Engineering, 5, 1-5.

Miller S.M., Fugate E.J, Craver V.O, Smith J.A. and Zimmerman J.B. (2008), Toward understanding the efficacy and mechanism of Opuntia spp. as a natural coagulant for potential application in water treatment, Environmental Science and Technology, 42(12), 4274-4279.

Radoiu M.T., Martin D.I., Calinescu I. and lovu H. (2004), Preparation of polyelectrolytes for wastewater treatment, Journal of Hazardous Materials, 106(1), 27-37.

Rajesh Banu J. and Kaliappan S. (2007), Treatment of tannery wastewater using hybrid up-flow anaerobic sludge blanket reactor, Journal of Environmental Engineering and Science, 6(4), 415-421.

Saukkoriipi J. (2010), Theoretical study of the hydrolysis of aluminum complexes, Series Acta Universitatis Ouluensis Scientiae Rerum Naturalium (A 554), PhD thesis, University of Oulu, Finland.

Sayers R.H. and Langlais R.J. (1977), Removal and recovery of sulfide tannery wastewater (Vol. 1). Environmental Protection Agency, Office of Research and Development, Industrial Environmental Research Laboratory.

Schrank S.G., Bieling U., Jose H.J., Moreira R.F.P.M. and Schroder H.F. (2009), Generation of endocrine disruptor compounds during ozone treatment of tannery wastewater confirmed by biological effect analysis and substance specific analysis, Water Science and Technology, 59(1), 31-38.

Shammas N. K. (2005), Coagulation and flocculation, Physicochemical treatment processes, 103-139.

Sharma S. and Adholeya A. (2011), Detoxification and accumulation of chromium from tannery effluent and spent chrome effluent by Paecilomyces lilacinus fungi, International Biodeterioration and Biodegradation, 65(2), 309-317.

Song Z., William C.J. and Edyvea, R G J. (2004), Treatment of tannery wastewater by chemical coagulation, Desalination, 164(3), 249-259.

Srivastava V.C., Mall I.D. and Mishra I.M. (2005), Treatment of pulp and paper mill wastewaters with poly aluminium chloride and bagasse fly ash, Colloids and Surfaces $A$ : Physicochemical and Engineering Aspects, 260(1), 17-28.

Sutherland J.P., Folkard G.K. and Grant W.D. (1989), Seeds of Moringa species as naturally occurring flocculants for water treatment, Science, Technology and Development, United Kingdom.

Talu G.F. and Diyamandoglu V. (2004), Formate ion decomposition in water under UV irradiation at $253.7 \mathrm{~nm}$, Environmental Science and Technology, 38(14), 3984-3993.

Vaananen M., Kupiainen L., Ramo, J., Sarpola A., and Tanskanen J. (2012), Speciation and coagulation performance of novel coagulant-Aluminium formate, Separation and Purification Technology, 86, 242-247.

Verma S., Prasad B. and Mishra I.M. (2010), Pre-treatment of petrochemical wastewater by coagulation and flocculation and the sludge characteristics, Journal of Hazardous Materials, 178(1), 1055-1064.

Wilson L.D. (2014), An overview of coagulation-flocculation technology, Water Cond. Purific Mag, 56, 28-34.
Yan M., Wang D., Qu J., He W. and Chow C.W. (2007), Relative importance of hydrolyzed $\mathrm{Al}$ (III) species (Al a, Al b, and Al c) during coagulation with polyaluminum chloride: a case study with the typical micro-polluted source waters, Journal of Colloid and Interface Science, 316(2), 482-489.

Zha Y.Q. and Bache D.H. (2002), Integrated effects of applied pressure, time, and polymer doses on alum sludge dewatering behaviour, Waste Management, 22(7), 813-819. 